\title{
Implementation Model of Integrated Industrial Estate Development Policy for Tukak Sadai Port in South Bangka Regency, Bangka Belitung Islands Province, Indonesia
}

\author{
Justiar Noer ${ }^{1}$, Khasan Effendy ${ }^{2}$, Ngadisah ${ }^{3}$, Sampara Lukman ${ }^{4}$ \\ 1,2,3,4 Institut Pemerintahan Dalam Negeri (IPDN), Indonesia \\ Email: justiar.noer@gmail.com
}

\begin{abstract}
The purpose of this study was to find a model for implementing the policy of developing the Integrated Industrial Estate off the Tukak Sadai Port in the South Bangka Regency, Bangka Belitung Islands Province. This research uses qualitative methods with data collection techniques such as observation, in-depth interviews, and literature studies. Data analysis was performed using triangulation techniques. The results found that the model of policy implementation needed to implement the policy of developing the Tukak Sadai Port IIE in the South Bangka Regency, Bangka Belitung Province was to include political, economic, social, and technological factors in Grindle's implementation theory (1980).
\end{abstract}

Keywords: policy implementation, new model, integrated industrial estate.

\section{A. INTRODUCTION}

Indonesia is the largest archipelago country in the world with three-quarters of its territory in the form of a sea with abundant natural resources and a large amount of service in the environmental sector, so the marine economy is a comparative advantage that can be transformed into competitive advantages and a source of new economic growth Indonesia. Therefore, the central and regional governments carry out synergy as an effort to develop the marine economy to realize Indonesia as the World Maritime Axis (Lasabuda, 2013).

South Bangka Regency is one of the three districts in the Bangka Belitung Islands Province with abundant natural resource potential in the field of plantations and marine products. Apart from natural potential, another potential possessed by South Bangka Regency is its strategic geographical position. South Bangka Regency is in the vicinity of IASC 1 (Indonesian Archipelago Sea Channel 1), which is traversed by international shipping lanes through Jakarta, Europe, Singapore, Hong Kong, Japan, and the United States. This position has geostrategic advantages that offer opportunities for the South Bangka region to capture the global supply chain for industrial, trade and logistics activities. 
There are a number of natural potentials and geostrategic advantages possessed by the South Bangka Regency that have not been effectively utilized to move the local economy. To spur economic growth and increase the competitiveness of South Bangka Regency against other regions in Indonesia, it is necessary to accelerate economic development which has a number of main prerequisites namely; increasing human resource capacity, increasing productivity, efficiency and added value of natural resources, strengthening the capacity of science and technology, providing integrated and equitable infrastructure with due regard to regional and global geostrategic positions.

The concept of accelerated development based on the comparative and competitive potential of South Bangka Regency requires the support of a number of components such as logistics systems, regional infrastructure, policies and regulations, space and regional management as well as regional transportation systems with industrial development as the main sector driving the economy. One of the government's efforts was realized by the plan to develop the Integrated Industrial Estate (IIE) of the Tukak Sadai Port which was able to accommodate various industrial activities in order to improve the economy of South Bangka Regency.

This industrial estate development policy is one of the appropriate strategies because industrial development is considered to be able to increase the competitiveness of regional commodities. Competitive production results, of course, will directly benefit and become capital that can be used to develop South Bangka Regency at a further level. The industrial estate is an area that is dominated by industrial activities that have a combination of facilities consisting of factory equipment, research facilities and laboratories for development, office buildings, banks, and social facilities and public facilities (Dirdjojuwono, 2004). Local governments need to develop the economy and investment in their regions. The development of industrial estates is important to increase economic growth, in order to create prosperity primarily through the provision of employment opportunities (Syahruddin, 2011). Through economic growth, one percent can absorb a workforce of around one hundred thousand people (Soeling, 2007).

The existence of the Integrated Industrial Estate (IIE) of Tukak Sadai Portals is considered potential because of the position of the South Bangka Regency which is traversed by the Indonesian Archipelago Sea Channel (IASC), making this district passed by many ships. Sailing ships are domestic and international vessels. The development of ports in the South Bangka Regency can also encourage the emergence of maritime supporting industries, in addition, it can give birth to the sea transportation industry and the warehousing industry.

Based on the description above, the purpose of this study is to find a model for implementing policies on the development of the Integrated Industrial Estate of Tukak Sadai Port in South Bangka Regency, Bangka Belitung Province, Indonesia. 


\section{B. LITERATURE REVIEW}

Policies are decisions based on rules and regulations made by authorized institutions or wise leaders in carrying out policies, so that policy implementation can be realized in accordance with the needs and development of the actual conditions of the strategic environment that can support government programs in the future. comes in providing service to the community (Suradinata, 2004).

As a concept, the policy has a broad meaning and multiple interpretations. Anderson (in Wahab, 1998) gives the meaning of policy as the behavior of actors in a particular field of activity. This understanding is very broad and can be interpreted in various ways, for example, the actor can be an individual or an organization; can be government or non-government. Likewise, with the term certain activities can be interpreted as administrative, political, economic activities and others. Besides that, the form of its activities is also broad and multi-interpretative, for example, it can be in the form of achievement of objectives, planning, programs, and so on. Thuswise studies are studies of the behavior of various actors in various fields of activity that have relevance to the actor.

According to Chander and Plano in Keban (2004), public policy is a strategic use of available resources to solve public or government problems. Even Chander and Plano also assume that "public policy is an ongoing intervention by the government for the benefit of certain groups of people so that they can play a role in the interests of the community groups so that they can play a role in the development as well as any actions undertaken by the government. Dwidjowijoto (2008) defines public policy as a decision made by the state, specifically the government, as a strategy to realize the objectives of the country concerned. Public policy is a strategy to take the community at an early stage. Entering the community at the time of transition, to go to the people they aspire to.

Based on various perspectives on the understanding of public policy above, it appears that public policy can only be determined by the government, other parties or better known as public policy actors can only influence the public policy process within their respective authorities.

Grindle Policy Implementation Theory (1980), shows that the success of policy implementation is determined by the content and context of the policy. According to Grindle, the contents of policies and programs are important factors in determining the results of implementation initiatives. But as many examples above show, and as shown in the content picture, policy or program is often an important factor because the real potential or impact may be on the given social, political, and economic arrangements. Therefore, it is necessary to consider the context or context in which administrative action is achieved. Often, the actors' goals will be in direct conflict with each other and the outcome of this conflict and its consequences, who gets what, will be determined by the strategy, resources, and power positions of each actor involved. What is implemented 
may be the result of the calculation of political interests and competing groups for scarce resources, the response from implementing officials, and the actions of political elites, all interacting in the given institutional context. Analysis of the implementation of special programs for this purpose can be interpreted as assessing the "ability" of actors, their interests and strategies to achieve them, and the characteristics of the regimes in which they interact. This, in turn, can make it easier to assess the potential for achieving program policies and objectives.

According to Grindle, in achieving goal officials face two problems highlighting the interaction of the program environment and program administration. First, officials must address the problem of how to achieve policy compliance. They must, for example, obtain support from the political elite, and compliance with implementing agencies, the imposition of bureaucracy by implementing programs from lower-level political elites, and beneficiaries. They must change the opposition from those who might be harmed by the program to their acceptance, and they must protect those who are excluded, but who want to benefit, from destroying them. Such an appearance can mean substantial bargaining, accommodation, and conflict compliance. However, if the overall policy objective is embodied, resources are transacted to obtain compliance that cannot jeopardize the impact of program specificity.

The other side of the policy problem and achieving program objectives in a certain environment in responsiveness. Ideally, public institutions such as the bureaucracy must be responsive to the most adequate needs for them to serve them. In addition, without sufficient responsiveness during implementation, public officials who lose information to evaluate program achievements and support can mean that policy objectives are not achieved because of interventions from the same individuals or groups, both in order to obtain specific types of goods and services in larger amounts or to hinder the fulfillment of certain programs that cannot be accepted by them as profitable.

\section{RESEARCH METHODS}

The type of research used in this study is a qualitative type (Bungin, 2007: Patton, 1990; Cassell \& Symon, 2004; Moleong, 2007; Creswell \& Poth, 2016). Data collection techniques, Primary data collection is done in three ways, namely in-depth interviews, field observations and literature studies (Creswell \& Miller, 2000). Data analysis is carried out inductively where the data obtained will be analyzed and developed into a basic assumption of research, then other data continues to be collected and conclusions are drawn. Data analysis in this study uses the model of Miles and Huberman (1984). The data collected is analyzed through several stages, namely data reduction, data display and conclusion drawing/verification so that a conclusion can be drawn. 


\section{RESULTS AND DISCUSSION}

The Implementation Model of the Tukak Sadai Port IIE Development which the authors will forward is the result of the development of the theory which serves as a theoretical foundation in developing research concepts. The Tukak Sadai Port IIE Development Implementation Model was prepared based on the empirical findings described in the previous discussion.

This study uses Grindle's (1980) policy implementation theory stating that "there are two things that determine the success of a policy, namely the content of the policy and the context of implementation. Content of policy includes Interests affected by the policy; relating to various interests that affect policy implementation. This indicator argues that policy in its implementation must involve many interests and the extent to which those interests have an influence on its implementation. Types of benefits to be generated; in this case, the content of policy seeks to show or explain that in policy there must be several types of benefits that indicate the positive impact produced by the implementation of wisdom. The extent of change envisioned; how much change is to be achieved through a policy implementation must have a clear scale. Site of decision making; decision making in a policy plays an important role in the implementation then it must be explained where the decision-maker of a policy will be implemented. Implementor program; in carrying out a policy must be supported by a competent and capable policy implementer for the success of the policy. Committed Resources; the implementation of wisdom must be supported by supporting resources so that the implementation is going well.

While the context of policy implementation (context of implementation) includes the Power, interests, and strategies of the actors involved (power, interest, and strategy of actors involved); in the implementation of a policy, it is necessary to take into account the power, interests, and strategies used, the characteristics of institutions and authorities (institution and regime characteristics); the environment in which a policy is implemented also has a bearing on successful implementation, and compliance and responsiveness (compliance and responsiveness); namely compliance and responsiveness of the implementer. Furthermore, in the Implementation of the Development of Tukak Sadai Port IIE in South Bangka Regency following the corridor of Regional Regulation No. 6 of 2014 concerning Spatial Planning and Regional (RTRW) of South Bangka Regency.

Regarding the discussion that the author has previously described supporting factors and inhibiting factors for the Implementation of the Tukak Sadai Port IIE Development based on the PEST analysis. First, from the political aspect, the supporting factor for the Implementation of the Tukak Sadai Port IIE Development is the political will of the Bangka Belitung Islands Province Government or the provincial government's political will has concretely supported the Implementation of the Tukak Sadai Port IIE Development by stipulating Regional Regulation Number 2 of 2014 concerning the 
RTRW of the Bangka Belitung Islands Province in which the Tukak Sadai Port IIE was established as a provincial strategic area, at least explaining zoning, the destruction of the area. But the inhibiting factor from the political aspect is the slow response of the central government to set the Tukak Sadai Port IIE to become the National Strategic Area (KSN) so that this becomes one of the obstacles in sharing various things, ranging from licensing in the area manager, to support from infrastructure development and also for support in regional development.

On the economic aspect, economic improvement has not yet been signed. However, there have been individual initiatives that have taken a role in development, such as selling food and beverages for regional needs. This comes from the social aspects of the community which is culturally the majority work as fishermen. The enthusiasm of the community for development seems to be high but they do not yet know what their role will be in the area, so there are still some people who prefer to become fishermen, involved in becoming manual laborers in the area. Although the Regional Government has had studies such as feasibility studies, this does not record the policy of developing the Tukak Sadai IIE because there are no specific Regional Regulations to explain the area.

The model is the result of the development of theory which is used as a theoretical basis for developing research concepts and as a bridge to reduce the gap between empire and theory. The model that the writer compiled based on the results of the discussion of the Implementation of the Development of the Tukak Sadai Port IIE then included Political, Economic, Social, and Technology factors in Grindle's implementation theory (1980). Following is the picture of the Implementation Model of the Tukak Sadai Port IIE Development, including: 


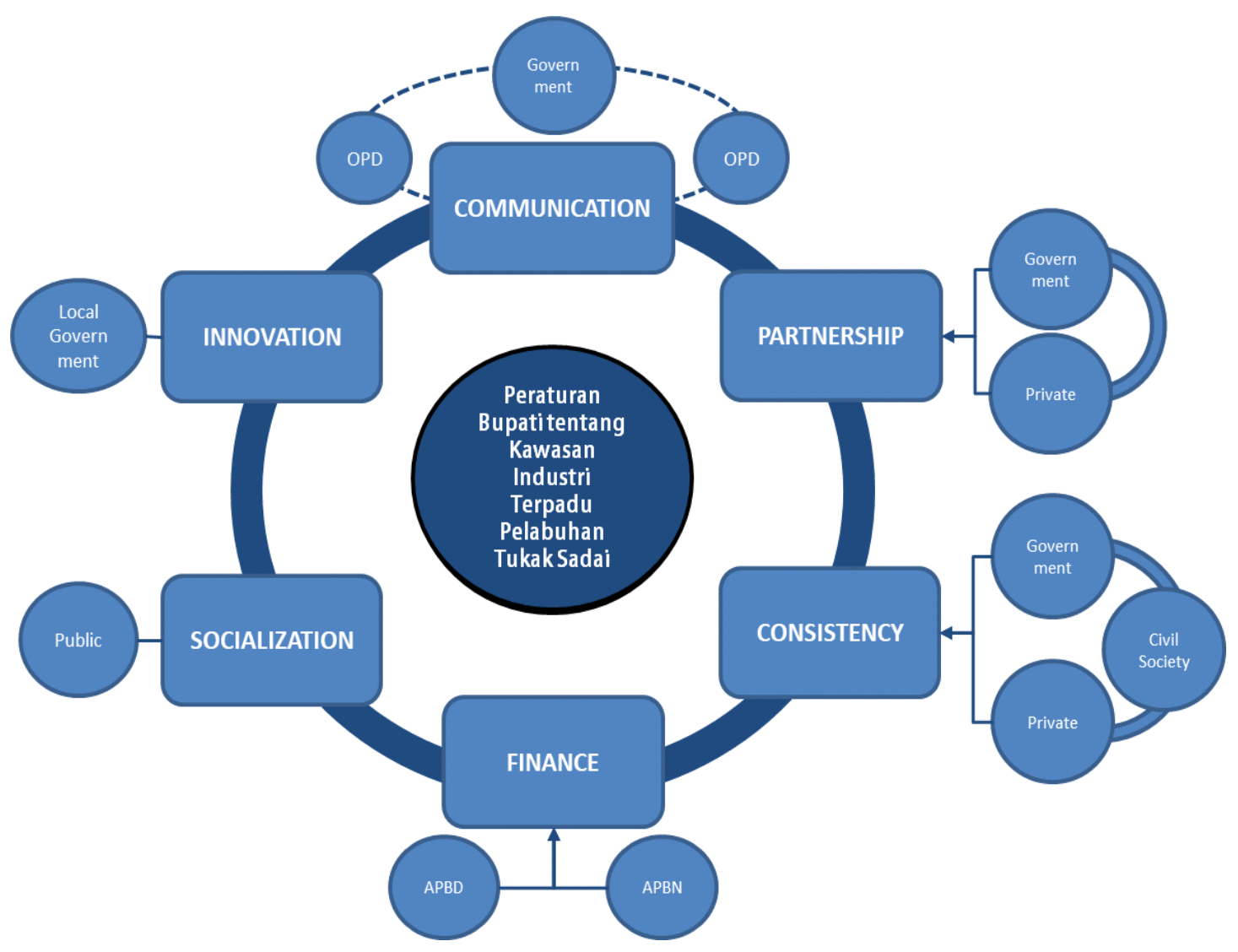

Figure 1 Implementation Model of the Tukak Sadai Port IIE

On the Communication dimension, the author evaluates how multi-level governance, communication and cooperation between layers of government influence the policy implementation process. The main problem in this is political stability, state ideology, industrial regulations, trade, and so on. Regional Apparatus Organization (OPD) is a strategic component in the Implementation of Tukak Sadai Port IIE Development.

The slow response from the central government to set the Tukak Sadai Port IIE to become a National Strategic Area (KSN) so that this becomes one of the obstacles in sharing various aspects ranging from licensing in the area manager, to support from infrastructure development and also to support regional development. In addition, the second obstacle is the absence of specific regulations regarding the Tukak Sadai Port IIE. This is of course very necessary to simplify the performance of the OPD because it already has a legal basis and can also regulate land use and can provide definite limits in the development of the Tukak Sadai Port IIE so as not to cause negative impacts that will arise in the future. Besides that, in the Tukak Sadai Port IIE, public opinion formation must be expected to also be able to encourage political will from various layers or levels of institutions. The creation of political will facilitate relations, communication, coordination, and reciprocity for the policy implementation process of developing the 
Tukak Sadai Port IIE. This is because it can go hand in hand with the establishment of synergistic transaction patterns between institutions. That implementing institutions play an important role in the process of policy implementation, especially for the central, provincial and regional governments, so that political will be able to form the basis for the formation of solid or strong communication and synergy among institutions. then this will have an important influence on the process of implementing the Tukak Sadai Port IIE to run optimally.

On the dimension of Partnership, the authors assess the need for cooperation between the Government (Government) with the Private (Private). In implementing development, the government can use several concepts. One of the concepts used is the Public-Private Partnership (PPP) scheme. The author offers this concept on the Partnership dimension because the private sector is seen as having qualified and qualified resources so that it can realize effective and efficient infrastructure development. Another thing that needs to be known in the Public-Private Partnership scheme is that the private sector will establish a Limited Liability Company which is only intended to carry out the project.

Public-Private Partnership (PPP) is a scheme for providing public infrastructure that involves the role of the private sector. PPP was first regulated in Presidential Regulation 67 of 2005 concerning Public-Private Partnership (PPP). The regulation was updated with the ratification of Presidential Regulation No. 38 of 2015 concerning PPP. Under the PPP scheme, the government and the private sector can share responsibilities and risks. The government will plan the construction of public infrastructure. Meanwhile, the role of the private sector is to provide and manage public infrastructure for an agreed period of time. Assistance from the private sector can reduce the expenditure of APBN and APBD in financing infrastructure development. So that the government can utilize the state budget or regional budget to run other programs that encourage economic growth.

On the Consistency dimension, the government as the policy initiator must be able to show consistency for the sake of creating legal certainty in the community. Consistency can also be an initial reason for investment or cooperation with the private sector to begin. Government development policies can be a trigger for economic growth and investment inflows. Policies taken by the government do not only concern the quantity. The government must produce quality, consistent, coherent and rational policies. Policy consistency is very important because it will create positive perceptions of (private) business operators.

Inconsistent policies will create negative perceptions of business actors and this will affect investment inflows and economic growth. The decline in public consumption is inseparable from the problem of business actors with government policies. The private sector does not only see the political situation as a problem. The private sector also highlights the consistency of policies taken by the government. If the government con- 
tinues to present contradictory and inconsistent regulations, that is a big problem for the private sector. As a result, there is a negative perception of the government. Employers also have no confidence in the government.

In the dimension of Finance, the authors assess the management of regional finances and political budgeting between the executive and legislative branches are still a problem. APBD, in this case, is a political activity, the process and its work products are political products related to who gets what, who is involved and the problems and conflicts that arise in the preparation of being able to determine the budget.

The implementation of the Tukak Sadai IIE Port Development Policy cannot be imposed on ABPD, bearing in mind that the burden of the APBD is already heavy enough to sustain the routine activities of the regional government. So the government as a policy initiator must be able to find other sources of the budget by utilizing the government's basic capital, namely capital power to the private sector that has economic capital so as to create strategic partnerships to accelerate regional development.

In the dimension of Socialization, it is seen as an effort to improve the quality of the policy itself. The problem that often arises when implementing policies is that there has been no socialization done by the government. Policy implementation activities will certainly be welcomed with joy by the community if the designation of the policy is truly for the good and has a direct impact on the wider community. In terms of the implementation of the policy on the development of the port of IIE Tukak Sadai, the author considers that socialization is sufficient in supporting the quality of the policy.

In the Innovation dimension as a strategic keyword when the outputs and outcomes in policies are unable to meet the demands and dynamics of an increasingly global society. At this point, innovation is needed to strengthen the policy sectors with a broader spectrum. Public policy innovation as a necessity in principle and substantive will provide reinforcement in responding and solving problems in the midst of society.

In this context, the capacity of the innovator becomes very important in carrying out an innovation because it will provide many benefits. The innovation aims to revitalize government administration, make it more pro-active, efficient, accountable and more service-oriented. Therefore, the ability of public officials to innovate will be a decisive role and must have prerequisites for adequate skills and knowledge. So the authors add "innovation" to be one of the best alternatives in the dimensions of public policy in the present and the future.

\section{CONCLUSION}

A new policy implementation model is needed to implement the Tukak Sadai Port Integrated Industrial Estate (IIE) development policy in South Bangka Regency, Bangka Belitung Province, based on theoretical development which is used as a theoretical basis for developing research concepts. The new model that the authors compiled 
based on the results of the study was to include factors of politics, economy, social, technology in the theory of implementation of Grindle (1980).

\section{REFERENCES}

1. Bugin, B. (2007). Penelitian Kualitatif, Komunikasi, Ekonomi Kebijakan Publik dan Ilmu Sosial lainnya, Jakarta, Prenada Media Group.

2. Cassell, C., \& Symon, G. (Eds.). (2004). Essential guide to qualitative methods in organizational research. Sage.

3. Creswell, J. W., \& Poth, C. N. (2016). Qualitative inquiry and research design: Choosing among five approaches. Sage publications.

4. Creswell, J. W., \& Miller, D. L. (2000). Determining validity in qualitative inquiry. Theory into practice, 39(3), 124-130.

5. Dirdjojuwono, R. W. (2004). Kawasan Industri Indonesia: Sebuah Konsep Perencanaan dan Aplikasinya. Bogor: Pustaka Wirausaha Muda.

6. Dwidjowijoto, R. N. (2008). Public Policy. Jakarta: Elek Media Komputindo.

7. Grindle, M. S. (1980). Politics and Policy Implementation in The Third World. New Jersey: Princeton University Press.

8. Keban, T. Y. (2004). Enam Dimensi Strategis Administrasi Publik, Konsep, Teori dan Isu. Yogyakarta: Gava Media.

9. Lasabuda, R. (2013). Pembangunan Wilayah Pesisir dan Lautan Dalam Perspektif Negara Kepulauan Republik Indonesia. Jurnal Ilmiah Platax, 1(2), 92-101.

10. Milles, M. B., \& Huberman, M. A. (1984). Qualitative Data Analysis. London: Sage Publication.

11. Moleong, L. J. (2007). Metodologi Penelitian Kualitatif. Bandung: Remaja Rosdakarya.

12. Presidential Regulation No. 38 of 2015 concerning Public-Private Partnership (PPP).

13. Regional Regulation No. 2 of 2014 concerning RTRW of Bangka Belitung Islands Province.

14. Regional Regulation No. 6 of 2014 concerning South Bangka Regency RTRW.

15. Satori, D. A., \& Komariah, A. (2009). Metodologi penelitian kualitatif. Bandung: Alfabeta.

16. Soeling, P. D. (2007). Pertumbuhan Bisnis dan Tanggung Jawab Sosial Perusahaan. Jurnal Ilmu Administrasi dan Organisasi, Bisnis E Birokrasi, 15(1).

17. Suradinata, E. (2004). Pembaharuan Birokrasi dan Kebijakan Publik. Jakarta: Erlangga.

18. Syahruddin, S. (2011). Evaluasi Implementasi Kebijakan Pengembangan Kawasan Industri. Bisnis E Birokrasi Journal, 17(1).

19. Wahab, S. A. (2008). Analisis Kebijakan: Dari Formulasi ke Implementasi Kebijakan Negara. Bumi Aksara. Jakarta. 